ECCOMAS

Proceedia
COMPDYN 2021

$8^{\text {th }}$ ECCOMAS Thematic Conference on Computational Methods in Structural Dynamics and Earthquake Engineering M. Papadrakakis, M. Fragiadakis (eds.) Streamed from Athens, Greece, 28 - 30 June 202

\title{
ASSESSMENT OF OUT-OF-PLANE STRENGTH OF MASONRY INFILLS ACCORDING TO EC6
}

\author{
L. Liberatore ${ }^{1}$ \\ ${ }^{1}$ Department of Structural and Geotechnical Engineering, Sapienza University of Rome \\ Via Gramsci, 53 - 00197 Rome, Italy \\ e-mail: laura.liberatore@uniroma1.it
}

\begin{abstract}
In the last decades the attention to the out-of-plane response of infills has been increasingly growing due to their influence on the global seismic behaviour of frame structures. In order to assess their out-of-plane capacity, different approaches have been proposed, such as those based on the arching effect and on the yield-line theory. Both methods are implemented in Eurocode 6 for masonry structures. The first approach is based on the observation that an arching effect develops in a wall provided that surrounding elements are able to resist thrust. The second approach consists in defining a kinematically admissible mechanism (yield-line mechanism) and calculating the limit load by equating the internal and external works. This method was implemented in Eurocode 6 (EC6) as well as in other codes by means of coefficients, which depend on the orthogonal ratio of the masonry flexural strengths, the degree of fixity at the edges of the wall and the wall aspect ratio. The suitability of the methods proposed in EC6 is investigated herein for masonry infills through comparison with experimental tests. It is found that, considering the second approach, the results are, on the average, conservative, contrary to the assumption that the method should provide an upper bound of the resistance.
\end{abstract}

Keywords: Infilled frames, Out-Of-Plane Collapse, Arching Effect, Yield-line Theory, Compressive Strength, Flexural Strength. 


\section{INTRODUCTION}

The influence of masonry infills to the structural response of frame buildings is widely recognized. The presence of regularly distributed infills is usually beneficial, due to their capacity to reduce the displacement demand and to dissipate energy [1-5]. On the other hand, irregular distributions due to the lack of one or more panels may lead to the increase of internal forces and displacements as well as to brittle failures [6-9]. In addition, the collapse of infills, especially in the out-of-plane (OOP) direction, occurs also for moderate intensity of the ground motion [10-13], causing casualty risks and economic losses. This explains the fact that in the last years the OOP response of infills and the interaction between in-plane (IP) and OOP actions have become issues of major concern [14-19]. Different methods have been put forward for their assessment, like those based on rigid body mechanisms or on numerical and iterative solutions [20,21]. The first category includes methods derived from the yield-line theory as well as methods which take into account the arching effect.

The first approach, based on the yield-line theory, was initially proposed to determine the collapse load of reinforced concrete slab [22,23] and was subsequently applied to masonry walls $[24,25]$. The method allows taking into account different strengths in two orthogonal directions and the bending resistance along supports. It consists in defining a kinematically admissible mechanism in which all deformations (rotations) take place along yield lines and edges, and the single portions of the wall rotate as rigid bodies (Figure 1a). The limit load is estimated by equating the internal work, which is given by the energy dissipated along the yield lines, to the external work, i.e. the work done by the applied loads. Among the infinite number of mechanisms, the collapse mechanism is the one that occurs under the smallest load. Considering the upper bound theorem of the limit analyses, it is possible to recognise that the yield-line method provides an upper bound of the wall strength. This method was implemented in Eurocode 6 [26] (EC6 hereinafter) as well as in other codes [27] by means of coefficients, which depend on the degree of fixity at the edges of the wall, the wall aspect ratio and the orthogonal ratio of the masonry flexural strengths.

The second approach is based on the observation that the arching effect develops in a wall provided that surrounding elements are able to resist thrust. In the one-way arching model, the collapse is associated to a three-hinge mechanism (Figure 1b), which is usually activated along the shorter dimension, and the collapse load depends on the masonry compressive strength and on the wall slenderness [28]. When the infill is restrained at four edges, a twoway arching action may develop, thus increasing the OOP strength [29,30]. The one-way arching method is included in EC6 which provides an equation of the limit load that can be used when lateral deflections are small.

The suitability of the methods proposed in EC6 for masonry structures and described in $\S 2$, is investigated herein for masonry infills through comparison with experimental tests. Specifically, a dataset of 71 experimental tests on one-storey one-bay infilled frames is compiled $(\S 3)$ and the related experimental OOP strengths are compared with those predicted by the EC6 formulations in $\S 4$. 


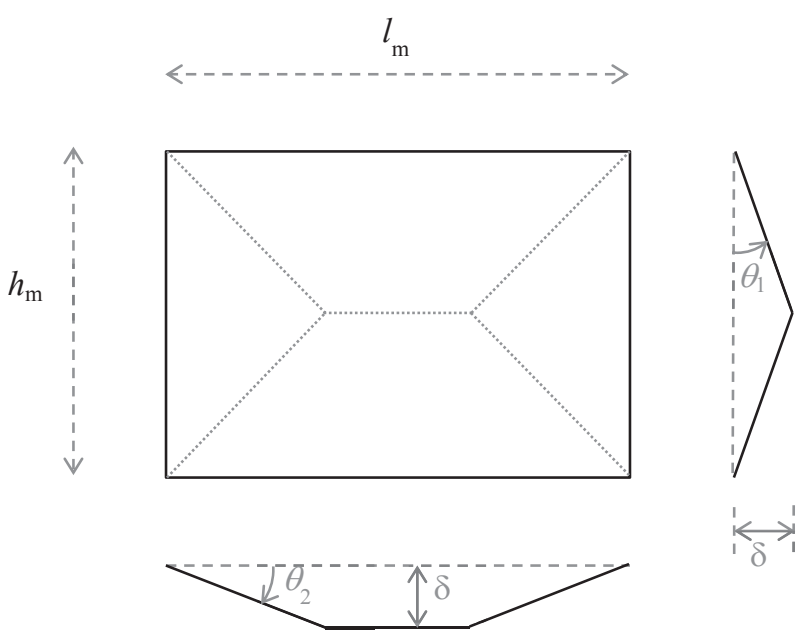

(a)

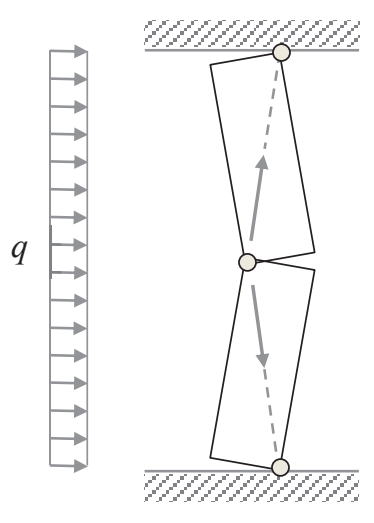

(b)

Figure 1: a) example of a kinematically admissible mechanism for an infill supported on four edges for use in the yield-line method; b) one-way arching model, the collapse is associated to a three-hinge mechanism.

\section{EC6 PREDICTIVE MODELS}

As mentioned above, the yield-line method was included in EC6 in form of tabulated coefficients. The procedure consists in verifying that the design value of the moments applied to a masonry wall does not exceed the corresponding moments of resistance. The design moments per unit length in two orthogonal directions, $M_{E d 1}$ and $M_{E d 2}$, acting on a wall subjected to the design lateral uniform pressure $q_{d}$ can be calculated as:

$$
\begin{aligned}
& M_{E d 1}=\alpha_{1} q_{d} l_{m}^{2} \\
& M_{E d 2}=\alpha_{2} q_{d} l_{m}^{2}
\end{aligned}
$$

while the moments of resistance as:

$$
\begin{aligned}
& M_{R d 1}=f_{x d 1} Z \\
& M_{R d 2}=f_{x d 2} Z
\end{aligned}
$$

where: $\alpha_{2}$ is a coefficient provided in Annex E of EC6; $\alpha_{1}=\mu \alpha_{2} ; \mu$ is the orthogonal ratio, i.e. the ratio between the flexural strength in the horizontal direction, $f_{x 1}$, and in the vertical direction, $f_{x 2}$ (Figure 2); $l_{m}$ is the length of the wall; $Z$ is the elastic section modulus of unit length of the wall:

$$
Z=t^{2} / 6
$$

and $t$ is the panel thickness.

The inequality between the design value of the applied moment and the design value of the moment of resistance gives:

$$
\begin{aligned}
& \alpha_{1} q_{d} l_{m}^{2} \leq f_{x d 1} Z \\
& \alpha_{2} q_{d} l_{m}^{2} \leq f_{x d 2} Z
\end{aligned}
$$


thus:

$$
q_{d} \leq \frac{f_{x d 2} Z}{\alpha_{2} l_{m}^{2}}
$$

Values of $\alpha_{2}$, which are provided in Annex E for different boundary conditions, orthogonal ratios and aspect ratios, are given by the following equation:

$$
\alpha_{2}=\frac{f_{x d 2} Z}{q l_{m}^{2}}
$$

where $q$ is the uniform load which leads to collapse, calculated through the yield-line theory. An example of calculations is reported in [31].
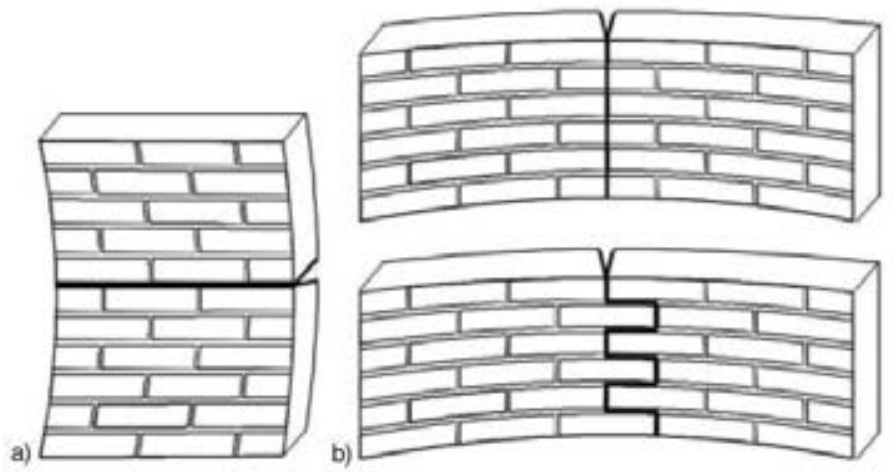

Figure 2: Plane of failure of masonry in bending: a) parallel to bed joints, flexural strength $f_{x 1}$; b) perpendicular to bed joints, flexural strength $f_{x 2}[26]$.

The other approach encompassed in EC6 is based on the assumption that an arching effect develops in unreinforced masonry walls having slenderness ratio not greater than 20 and design value of the vertical stress not less than $0.1 \mathrm{MPa}$. In these cases, a wall subjected to lateral loading may be designed by employing the following equation:

$$
q_{d}=f_{d}\left(\frac{t}{l_{a}}\right)^{2}
$$

where: $q_{d}$ is the design lateral strength per unit area; $f_{d}$ is the design compressive strength of the masonry in the direction of the arch thrust; $l_{a}$ is the length or the height of the wall depending on the direction along which the arching effect develops and $t$ is the wall thickness.

Finally, it is worthwhile to mention that Eurocode 8 [32] suggests measures to avoid the OOP collapse of slender masonry panels with specific reference to panels with slenderness ratio greater than 15. Examples of measures for the improvement of both IP and OOP response include the use light wire meshes, wall ties fixed to the columns, wind-posts and concrete belts.

\section{EXPERIMENTAL TESTS}

Seventy-one experimental tests are employed in this study (Table 1). Both infilled reinforced concrete and steel frames are considered as well as confined masonries. The slenderness ratio, $s r=l_{a} / t$, and the aspect ratio, $a r=h_{m} / l_{m}$, vary in the range 7-34 and $0.5-1.0$, respectively (Table 2 ).

The walls were made up of clay bricks having horizontal or vertical hollows, solid clay bricks and concrete blocks having vertical hollows, as specified in Table 2. The masonry 
compressive strength varies between 0.5 and $28.1 \mathrm{MPa}$. However, in $80 \%$ of the cases it not greater than 15.0 MPa, higher values are related to concrete block infills.

In 39 tests the infill were loaded in the OOP direction only. Generally, the OOP loads were applied monotonically by means of airbags, in some cases they were applied at four points or at mid-height.

The interaction between IP and OOP actions was considered in 32 tests, where an IP horizontal displacement was applied at the beam level prior to the OOP load. Maximum IP interstorey drift ratios $(I D R)$ are specified in Table 1.

\begin{tabular}{|c|c|c|c|c|c|c|}
\hline Reference & $\mathrm{OOP}^{(1)}$ & $\begin{array}{l}\text { IP- } \\
\text { OOP }^{(2)}\end{array}$ & Frame $^{(3)}$ & $\begin{array}{l}\text { Supported } \\
\text { edges }\end{array}$ & $I D R^{(5)}(\%)$ & $\begin{array}{l}\text { OOP } \\
\text { load type }\end{array}$ \\
\hline Dawe and Seah (1989) [29] & 6 & - & Steel & $\begin{array}{l}3(1 \text { test }), \\
4(5 \text { tests })\end{array}$ & - & airbag \\
\hline Angel et al. (1994) [33] & 1 & 5 & $\mathrm{RC}$ & 4 & $\begin{array}{l}0.22,0.25 \\
0.34\end{array}$ & airbag \\
\hline $\begin{array}{l}\text { Flanagan (1994) [34] } \\
\text { Flanagan and Bennett (1999) [35] }\end{array}$ & 3 & 2 & Steel & 4 & $0.42,0.84$ & airbag \\
\hline Calvi and Bolognini (2001) [36] & 1 & 2 & $\mathrm{RC}$ & 4 & $0.4,1.2$ & $\begin{array}{l}\text { four } \\
\text { points }\end{array}$ \\
\hline $\begin{array}{l}\text { Pereira et al. }(2011,2014) \\
{[37,38]}\end{array}$ & - & 4 & $\mathrm{RC}$ & 4 & 0.5 & airbag \\
\hline Varela-Rivera et al. (2011) [39] & 6 & - & $\mathrm{CM}$ & $\begin{array}{l}3 \text { (3 tests) } \\
4 \text { (3 tests) }\end{array}$ & - & airbag \\
\hline Varela-Rivera et al. (2012) [40] & 6 & - & $\mathrm{CM}$ & 4 & - & airbag \\
\hline Da Porto et al. (2013) [41] & - & 3 & $\mathrm{RC}$ & 4 & $0.5,0.19$ & $\begin{array}{l}\text { four } \\
\text { points }\end{array}$ \\
\hline Hak et al. (2014) [42] & - & 3 & $\mathrm{RC}$ & 4 & $\begin{array}{l}1.0,1.5 \\
2.5\end{array}$ & $\begin{array}{l}\text { mid- } \\
\text { height }\end{array}$ \\
\hline Furtado et al. (2016) [43] & 2 & 1 & $\mathrm{RC}$ & 4 & 0.5 & airbag \\
\hline Akhoundi et al. (2016) [44] & 1 & - & $\mathrm{RC}$ & 4 & - & airbag \\
\hline Wang (2017) [45] & 3 & 1 & $\begin{array}{l}\mathrm{RC}(3 \text { tests }) \\
\text { Steel ( } 1 \text { test) }\end{array}$ & $\begin{array}{l}3 \text { ( } 1 \text { test }) \\
4 \text { ( } 3 \text { tests })\end{array}$ & 1.34 & airbag \\
\hline Sepasdar (2017) [46] & 2 & 2 & $\mathrm{RC}$ & 4 & $0.65,1.7$ & airbag \\
\hline Ricci et al. (2018) [47] & 1 & 3 & $\mathrm{RC}$ & 4 & $\begin{array}{l}0.16,0.37 \\
0.58\end{array}$ & $\begin{array}{l}\text { four } \\
\text { points }\end{array}$ \\
\hline De Risi et al. (2019) [48] & 1 & 3 & $\mathrm{RC}$ & 4 & $\begin{array}{l}0.15,0.28 \\
0.51\end{array}$ & $\begin{array}{l}\text { four } \\
\text { points }\end{array}$ \\
\hline Di Domenico et al. (2019) [49] & 3 & - & $\mathrm{RC}$ & $\begin{array}{l}3 \text { (2 tests) } \\
4 \text { (1 test) }\end{array}$ & - & $\begin{array}{l}\text { four } \\
\text { points }\end{array}$ \\
\hline Akhoundi et al. (2020) [50] & 3 & 3 & $\mathrm{RC}$ & 4 & $\begin{array}{l}0.3,0.5 \\
1.0\end{array}$ & airbag \\
\hline \multicolumn{7}{|c|}{$\begin{array}{l}\text { (1) number of tests subjected to OOP loads only; } \\
\text { (2) number of tests subjected to IP drift and OOP load; } \\
\text { (3) Frame material: RC = Reinforced Concrete, CM = Confined Masonry; } \\
\text { (4) number of supported edges; } \\
\text { (5) Interstory Drift Ratio. }\end{array}$} \\
\hline
\end{tabular}

Table 1: Experimental tests on infilled frames. 


\begin{tabular}{|c|c|c|c|c|}
\hline Reference & Masonry units ${ }^{(1)}$ & $f_{m}^{(2)}(\mathrm{MPa})$ & $s r^{(3)}$ & $a r^{(4)}$ \\
\hline Dawe and Seah (1989) [29] & concrete blocks, vh & $20.20-28.10$ & $15-31$ & 0.78 \\
\hline Angel et al. (1994) [33] & solid clay bricks & $4.6-11.5$ & $17-34$ & 0.67 \\
\hline $\begin{array}{l}\text { Flanagan (1994) [34] } \\
\text { Flanagan and Bennett (1999) [35] }\end{array}$ & clay bricks, hh & $2.29-5.59$ & $7-24$ & 1.00 \\
\hline Calvi and Bolognini (2001) [36] & clay bricks, hh & 1.1 & 20 & 0.66 \\
\hline $\begin{array}{l}\text { Pereira et al. }(2011,2014) \\
{[37,38]}\end{array}$ & clay bricks, hh & $1.26-1.34$ & $11-19$ & 0.51 \\
\hline Varela-Rivera et al. (2011) [39] & concrete blocks, vh & 3.0 & $12-24$ & 0.49 \\
\hline Varela-Rivera et al. (2012) [40] & concrete blocks, vh & $2.45-2.84$ & $18-24$ & $0.74-0.95$ \\
\hline Da Porto et al. (2013) [41] & $\begin{array}{l}\text { clay bricks, hh (1 } \\
\text { test) and vh ( } 2 \text { tests })\end{array}$ & $2.0-6.0$ & $9-22$ & 0.64 \\
\hline Hak et al. (2014) [42] & clay bricks, vh & 4.64 & 8 & 0.70 \\
\hline Furtado et al. (2016) [43] & clay bricks, hh & 0.53 & 15 & 0.55 \\
\hline Akhoundi et al. (2016) [44] & clay bricks, hh & 1.59 & 20 & 0.68 \\
\hline Wang (2017) [45] & concrete blocks, vh & $7.9-9.0$ & $11-15$ & 0.73 \\
\hline Sepasdar (2017) [46] & concrete blocks, vh & $9.4-9.7$ & 11 & 0.73 \\
\hline Ricci et al. (2018) [47] & clay bricks, hh & 1.80 & 23 & 0.78 \\
\hline De Risi et al. (2019) [48] & clay bricks, hh & 2.37 & 23 & 1.00 \\
\hline Di Domenico et al. (2019) [49] & clay bricks, hh & $1.65-2.44$ & $15-29$ & 0.78 \\
\hline Akhoundi et al. (2020) [50] & clay bricks, hh & 1.17 & 20 & 0.68 \\
\hline $\begin{array}{l}\text { (1) } \mathrm{hh}=\text { horizontal hollows, } \mathrm{vh}=\mathrm{ve} \\
\text { (2) masonry compressive strength; } \\
\text { (3) slenderness ratio; } \\
\text { (4) aspect ratio. }\end{array}$ & tical hollows; & & & \\
\hline
\end{tabular}

Table 2: Experimental tests on infilled frames, mechanical and geometrical data.

\section{ASSESSMENT OF EC6 MODELS}

In order to compare the OOP strength predicted by the formulations reported in EC6 (Eq. 8 and Eq. 10) with the strength obtained in experimental test, the following assumption are made.

- The experimental flexural strength, $f_{x 2}$, is employed in Eq. 8 instead of the design flexural strength, $f_{x d 2}$. When the former value was not available, the flexural strength provided by EC6 for different masonry types was adopted. Such value was multiplied by 1.5 to obtain a mean value from the characteristic one.

- Similarly, when the orthogonal ratio was not available from experimental campaigns, it was derived from EC6.

- The experimental compressive strength of masonry, $f_{m}$, is used in Eq. 10 in the place of the design strength, $f_{d}$, for a consistent comparison with experimental tests.

- Eq. 10 is applied also in case of walls having slenderness ratio greater than 20 in order to investigate the influence of such parameter.

Therefore, the predicted OOP strength, $q_{\text {pred }}$, is determined as

$$
q_{\text {pred }}=\frac{f_{x 2} Z}{\alpha_{2} l_{m}^{2}}
$$

and

$$
q_{\text {pred }}=f_{m}\left(\frac{t}{l_{a}}\right)^{2}
$$

according to whether the method is based on the yield-line theory (Eq. 11) or on the arching effect (Eq. 12). As mentioned in $\S 2, l_{a}$ is the dimension of the wall in the direction along 
which the arching effect develops. Therefore, in case of infills having a top gap $l_{a}$ is the wall length, whereas for infills supported along four edges, it is the height, since aspect ratios are not greater than 1.0.

The experimental strength, $q_{\text {exp }}$, is the maximum OOP pressure recorded during the tests. In cases where the OOP load was applied in concentrated points, an equivalent uniform pressure was estimated so as to provide the same maximum bending moment as the concentrated forces.

\subsection{Results}

The comparison between predicted $\left(q_{\text {pred }}\right)$ and experimental $\left(q_{\text {exp }}\right)$ OOP strength is shown in Figure 3 to 5 , where the ratio $q_{\text {pred }} / q_{\text {exp }}$ is plotted against the masonry compressive strength, the slenderness ratio, the aspect ratio and the IDR. The mean and the mean \pm one standard deviation of $q_{\text {pred }} / q_{\text {exp }}$ are also shown. The expressions "yield line" and "arching action" used in the figures refer to the application of Eq. 11 and Eq. 12, which are based on the two approaches, respectively.

In Figures 3 and 4 only pure OOP tests are reported. First of all, it is noticed that the application of the arching action approach leads to a considerable overestimation of the strength when the masonry compressive strength $f_{m}$ is greater than $20 \mathrm{MPa}$, while it underestimates the strength when $f_{m}$ is less than $2 \mathrm{MPa}$ (Figure 2a). This outcome implies that $q$ and $f_{m}$ are not linearly proportional to one another and that Eq. 12 should not be used for strong masonries. In the following comparisons, such cases (6 tests) are disregarded.

On the average, both methods underestimate the strength, being the mean ratio between predicted and experimental values equal to 0.51 and 0.86 in case of predictions obtained through the yield-line theory (Eq. 11) and the one-way arching effect method (Eq.12), respectively. However, the application of Eq. 12 leads to a significant scatter due also to the fact that it does not take into account the effect of the aspect ratio. The yield-line method gives more conservative results and a smaller scatter.

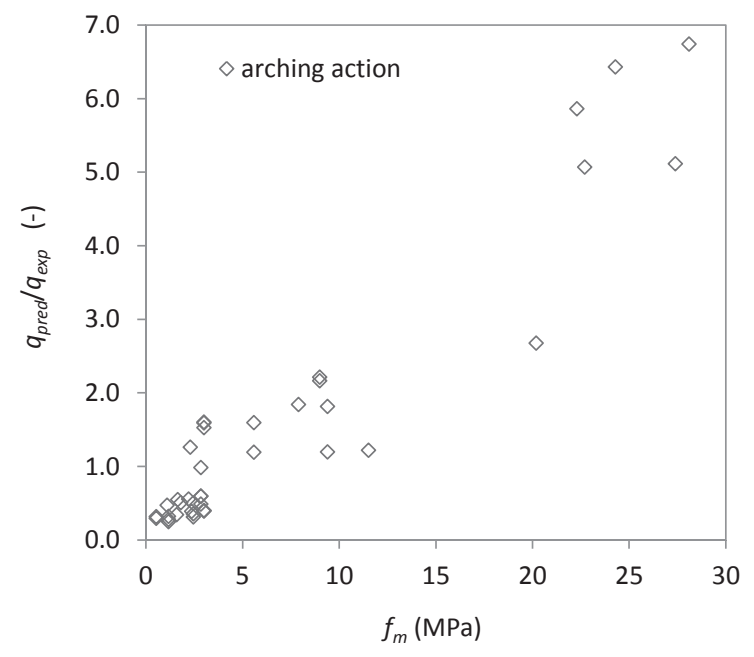

(a)

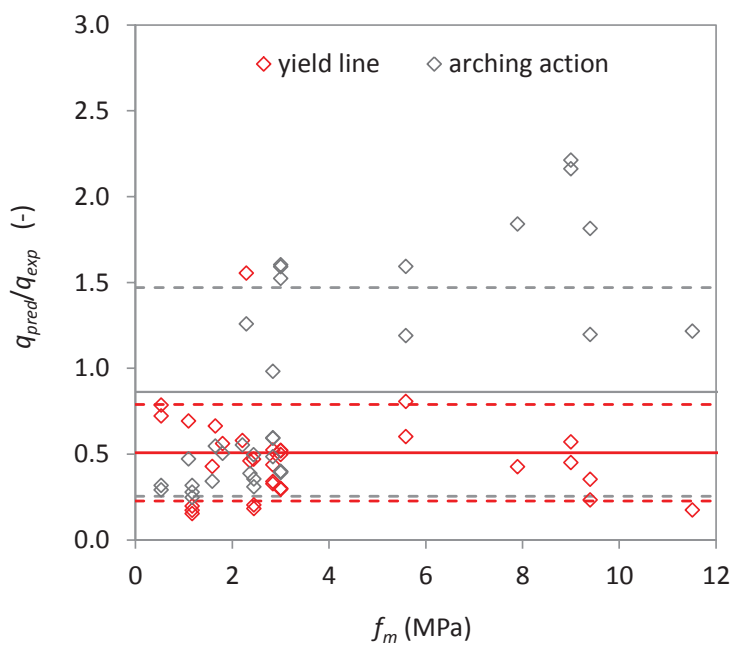

(b)

Figure 3: Ratio between predicted and experimental values of the OOP strength (for tests loaded OOP only) plotted against the masonry compressive strength. Continuous lines represent the mean values, dotted lines represent the mean \pm one standard deviation: red $=$ yield line, grey $=$ arching effect. 


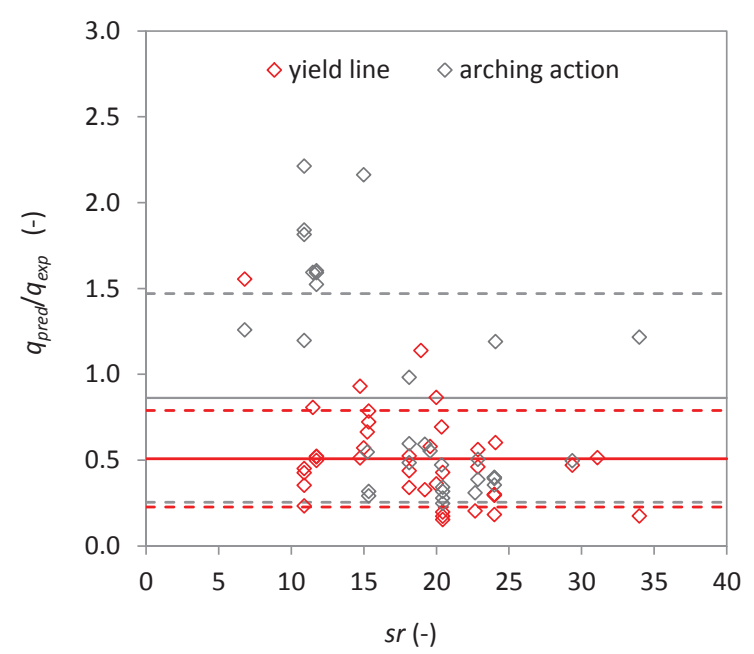

(a)

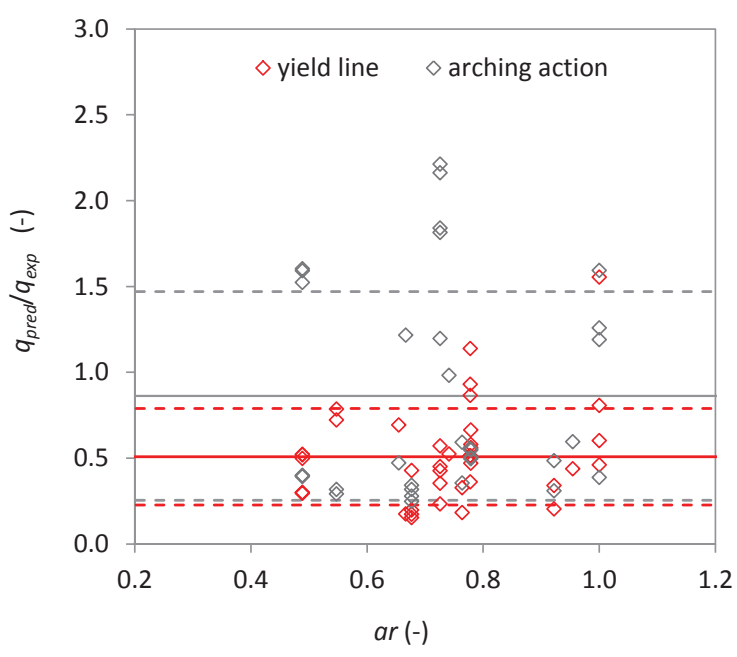

(b)

Figure 4: Ratio between predicted and experimental values of the OOP strength (for tests loaded OOP only) plotted against the slenderness ratio (a) and the aspect ratio (b). Continuous lines represent the mean values, dotted lines represent the mean \pm one standard deviation: red $=$ yield line, grey $=$ arching effect.

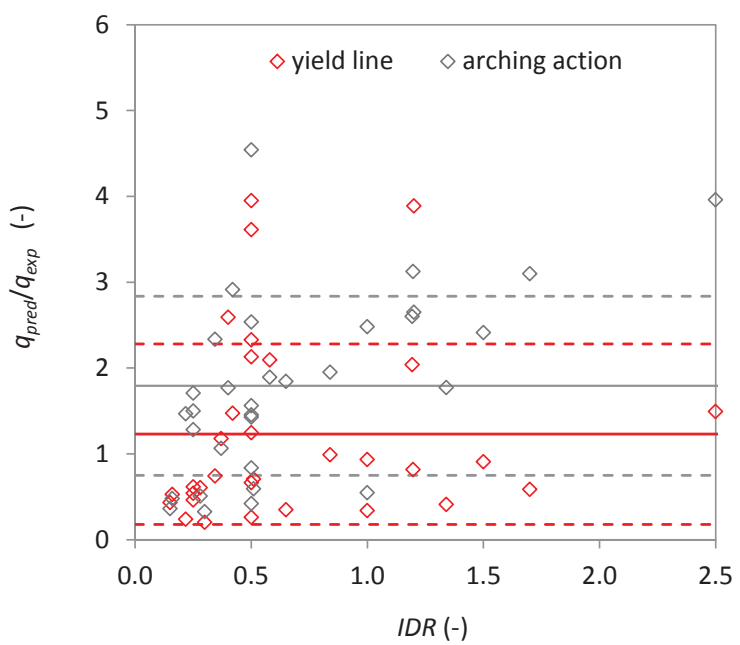

Figure 5: Ratio between predicted and experimental values of the OOP strength (for tests loaded to IP drift + OOP load) plotted against the IP interstory drift ratio (IDR). Continuous lines represent the mean values, dotted lines represent the mean \pm one standard deviation: $r e d=$ yield line, grey $=$ arching effect.

Figure 4 shows that, contrary to what expected, the predictive capacity of Eq. 12 does not worsen for slenderness ratios greater than 20. In general, the ability of the two methods in predicting the strength does not show a clear trend with varying aspect and slenderness ratios.

The predictions in case of previous IP damage are reported in Figure 5. Obviously, in this case both models overestimate, on the average, the experimental values. In fact, they do not account for previous IP damage. Also in this case, Eq. 11 gives more conservative results.

Finally, the yield-line equations provide the collapse mechanisms related to the minimum collapse pressure [31]. In Figure 6 the occurrences of predicted mechanisms is reported as a function of the infill aspect ratio. "Type 1" mechanisms (Figure 6a) refer to those cases which are most frequently observed in experimental campaigns: for infills supported along four edges the collapse mechanism is related to a first horizontal crack followed by inclined cracks 
running to the corners of the panel; for infills with no support along the top, a vertical crack develops at the centre of the panel followed by inclined cracks running to the bottom corners. In "type 2" mechanisms, the first crack is vertical for panels supported along four edges, whereas in panel with a top gap only inclined cracks develop (Figure 6b). Figure 6c indicates that "type 1" mechanisms develop when ar is in the range 0.49-078, whereas "type 2" mechanisms occur when ar ranges between 0.64 and 1.00. The yield-line method predicts the "type 2" mechanism more frequently than "type 1", in contrast to what observed experimentally. In fact, the method is not always able to predict the experimental collapse mechanisms, which are often a combination of different failure modes.

a)

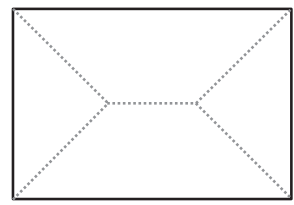

b)
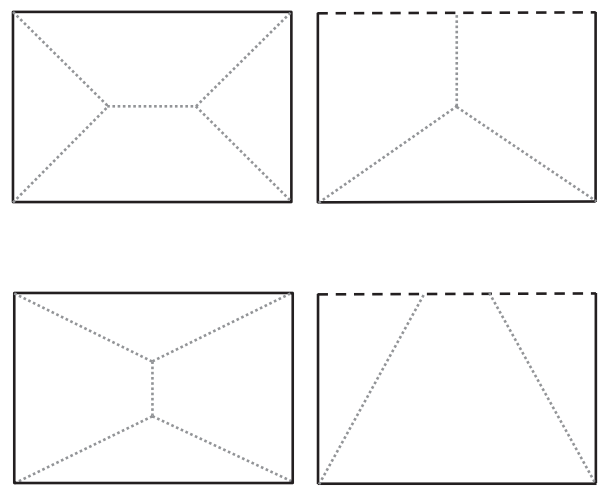
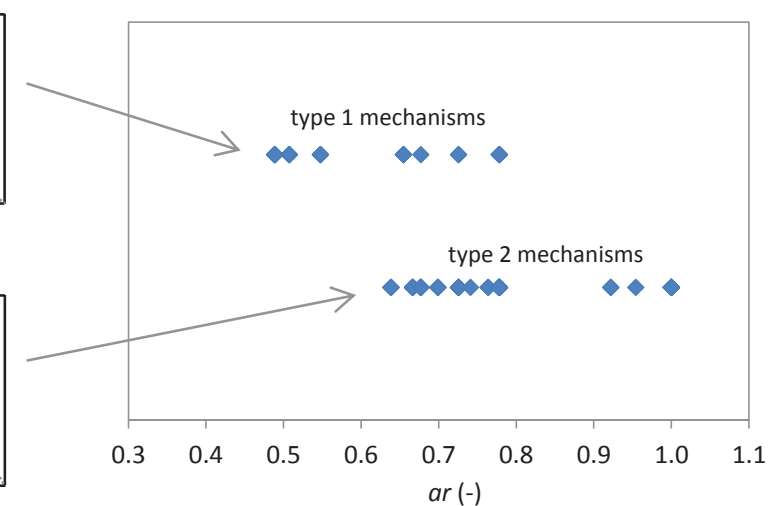

c)

Figure 6: a) crack patterns of type 1 collapse mechanisms; b) crack patterns of type 2 collapse mechanisms; c) occurrences of predicted collapse mechanisms.

\section{CONCLUSIONS}

In this study the methods encompassed in EC6 to determine the OOP strength of masonry walls are investigated to evaluate their possible suitability for infills. To this aim, a dataset of 71 experimental tests available in the literature is employed. The following conclusions are inferred:

- Eq. 11, based on the yield-line theory, is, on the average, conservative. In this case, the mean value of the ratio between predicted and experimental values is equal to 0.51 . This is probably due to the fact that the masonry flexural strength used to estimate the OOP resistance is derived from tests on simply supported specimen and therefore does not account for the confining effect of the frame.

- On the average, Eq. 12, which is based on the one-way arching effect, is slightly conservative, being the mean value of the ratio between predicted and experimental values equal to 0.86 . However, the scatter of data is noticeable, also because the two-way arching action and the influence of the aspect ratio are not taken into account by the model.

- The effect of previous IP damage is not considered in the examined formulations and therefore, as expected, the predictions are unconservative when previous IDR was applied to the infilled frame. The mean value of the ratio between predicted and experimental strength is equal to 1.23 and 1.79 when using Eq. 11 and Eq. 12, respectively.

- The yield-line method is not always able to predict the experimental crack patterns related to the collapse mechanisms observed experimentally. 


\section{REFERENCES}

[1] Dolšek M, Fajfar P. The effect of masonry infills on the seismic response of a four storey reinforced concrete frame-a probabilistic assessment. Eng Struct 2008;30:318692. doi:10.1016/j.engstruct.2008.04.031.

[2] Cavaleri L, Di Trapani F. Cyclic response of masonry infilled RC frames: Experimental results and simplified modeling. Soil Dyn Earthq Eng 2014;65:224-42. doi:10.1016/j.soildyn.2014.06.016.

[3] Liberatore L, Mollaioli F. Influence of Masonry Infill Modelling on the Seismic Response of Reinforced Concrete Frames. Proc. Fifteenth Int. Conf. Civil, Struct. Environ. Eng. Comput., 2015. doi:10.4203/ccp.108.87.

[4] Liberatore L, Noto F, Mollaioli F, Franchin P. Comparative assessment of strut models for the modelling of in-plane seismic response of infill walls. COMPDYN 2017, 6th Int. Conf. Comput. Methods Struct. Dyn. Earthq. Eng., 2017. doi:10.7712/120117.5643.17476.

[5] Liberatore L, Noto F, Mollaioli F, Franchin P. In-plane response of masonry infill walls: Comprehensive experimentally-based equivalent strut model for deterministic and probabilistic analysis. Eng Struct 2018;167:533-48. doi:10.1016/j.engstruct.2018.04.057.

[6] Verderame GM, De Luca F, Ricci P, Manfredi G. Preliminary analysis of a soft-storey mechanism after the 2009 L'Aquila earthquake. Earthq Eng Struct Dyn 2011;40:92544. doi:10.1002/eqe.1069.

[7] Liberatore L, Decanini LD. Effect of infills on the seismic response of high-rise RC buildings designed as bare according to Eurocode 8. Ing Sismica 2011;28:7-23.

[8] Tanganelli M, Viti S, de Stefano M, Reinhorn AM. Influence of infill panels on the seismic response of existing RC buildings: A case study. Geotech Geol Earthq Eng 2013;24:119-33. doi:10.1007/978-94-007-5377-8_9.

[9] Blasi G, De Luca F, Aiello MA. Brittle failure in RC masonry infilled frames: The role of infill overstrength. Eng Struct 2018. doi:10.1016/j.engstruct.2018.09.079.

[10] Decanini LD, Liberatore L, Mollaioli F. Damage potential of the 2009 L'aquila, Italy, earthquake. J Earthq Tsunami 2012;6. doi:10.1142/S1793431112500327.

[11] Inel M, Ozmen HB, Akyol E. Observations on the building damages after 19 May 2011 Simav (Turkey) earthquake. Bull Earthq Eng 2013;11:255-83. doi:10.1007/s10518012-9414-3.

[12] Masi A, Chiauzzi L, Santarsiero G, Manfredi V, Biondi S, Spacone E, et al. Seismic response of $\mathrm{RC}$ buildings during the Mw 6.0 August 24, 2016 Central Italy earthquake: the Amatrice case study. Bull Earthq Eng 2017:1-24. doi:10.1007/s10518-017-0277-5.

[13] Mollaioli F, AlShawa O, Liberatore L, Liberatore D, Sorrentino L. Seismic demand of the 2016-2017 Central Italy earthquakes. Bull Earthq Eng 2018. doi:10.1007/s10518018-0449-y.

[14] Mosalam KM, Günay S. Progressive collapse analysis of reinforced concrete frames with unreinforced masonry infill walls considering in-plane/out-of-plane interaction. Earthq Spectra 2015;31:921-43. doi:10.1193/062113EQS165M. 
[15] Ricci P, Di Domenico M, Verderame GM. Empirical-based out-of-plane URM infill wall model accounting for the interaction with in-plane demand. Earthq Eng Struct Dyn 2018. doi:10.1002/eqe.2992.

[16] Liberatore L, Pasca M. Assessment of the Out-of-Plane Resistance of Masonry Infill Walls. Proc. Fifteenth Int. Conf. Civil, Struct. Environ. Eng. Comput., 2015. doi:10.4203/ccp.108.173.

[17] Liberatore L, Marson C, AlShawa O, Pasca M, Sorrentino L. Failure of masonry infill walls under out-of-plane loads. Proc Int Mason Soc Conf 2018:78-88.

[18] Zizzo M, Cavaleri L, Di Trapani F. Out of Plane Capacity of Infills After in Plane Loading: a Prediction Analitical Model. COMPDYN 2019, 7th ECCOMAS Themat. Conf. Comput. Methods Struct. Dyn. Earthq. Eng., Crete, Greece, 24-26 June: 2019.

[19] Liberatore L, AlShawa O, Marson C, Pasca M, Sorrentino L. Out-of-plane capacity equations for masonry infill walls accounting for openings and boundary conditions. Eng Struct 2020. doi:10.1016/j.engstruct.2020.110198.

[20] Pasca M, Liberatore L, Masiani R. Reliability of analytical models for the prediction of out-of-plane capacity of masonry infills. Struct Eng Mech 2017;64:765-81. doi:10.12989/sem.2017.64.6.765.

[21] Liberatore L, Bruno M, Al Shawa O, Pasca M, Sorrentino L. Finite-discrete element modelling of masonry infill walls subjected to out-of-plane loads. ECCOMAS Congr. 2016 - Proc. 7th Eur. Congr. Comput. Methods Appl. Sci. Eng., vol. 3, 2016. doi:10.7712/100016.2175.8924.

[22] Johansen K. Yield-Line Theory. Copenhagen: Cement and Concrete Association, London; 1962.

[23] Johansen K. Yield-Line Formulae for Slabs. London: Cement and Concrete Association; 1972.

[24] Hendry A. The lateral strength of unreinforced brickwork. Struct Eng 1973;51:43-50.

[25] Haseltine B, West H, Tutt J. Design of walls to resist laterral loads. Struct Eng 1977;55:422-30.

[26] Eurocode 6. Design of Structures for Earthquake Resistance, Part 1: General rules, seismic actions and rules for buildings Masonry Structures, European Committee for Standardization; Brussels, Belgium. 2005.

[27] Bakeer T. Theoretical Verification of Existing Solutions on Lateral Loading of Masonry Infill Walls. Mauerwerk 2011;15:35-42. doi:10.1002/dama.201100487.

[28] McDowell EL, McKee KE, Sevin E. Arching theory of masonry walls. J Struct Div 1956;82:915-1-915-8.

[29] Dawe JL, Seah CK. Out-of-plane resistance of concrete masonry infilled panels. Can J Civ Eng 1989;16:854-64. doi:10.1139/189-128.

[30] Bashandy T, Rubiano N, Klingner R. Evaluation and Analytical Verification of Infilled Frame Test Data. 1995.

[31] Liberatore L, AlShawa O. On The Application Of The Yield-Line Method To Masonry Infills Subjected To Combined In-Plane And Out-Of-Plane Loads. Structures 2021;32:1287-301. 
[32] EC8-1. Eurocode 8: Design of structures for earthquake resistance-Part 1: General rules, seismic actions and rules for buildings. Brussels: European Committee for Standardization; 2004.

[33] Angel R, Abrams D, Shapiro D, Uzarski J, Webster M. Behavior of Reinforced Concrete Frames with Masonry Infills, University of Illinois Engineering Experiment Station. College of Engineering. University of Illinois at Urbana-Champaign. ISSN: 0069-4274. vol. SRS-589. 1994.

[34] Flanagan RD. Behavior of structural clay tile infilled frames. University of Tennessee, Knoxville, 1994.

[35] Flanagan R, Bennett R. Bidirectional behavior of structural clay tile infilled frames. J Struct Eng 1999;125:236-44. doi:10.1061/(ASCE)0733-9445(1999)125:3(236).

[36] Calvi GM, Bolognini D. Seismic response of reinforced concrete frames infilled with weakly reinforced masonry panels. J Earthq Eng 2001;5:153-85. doi:10.1080/13632460109350390.

[37] Pereira MFP, Pereira MFN, Ferreira JED, Lourenço PB. Behavior of masonry infill panels in RC frames subjected to in plane and out of plane loads. Amcm2011 - 7th Int Conf Anal Model New Concepts Concr Mason Struct 2011.

[38] Pereira MFP, Pereira MFN, Ferreira JE, Lourenço PB. Infill Masonry : Simple Analytical Methods for Seismic Design. 9th Int Mason Conf 2014:1-12.

[39] Varela-Rivera JL, Navarrete-Macias D, Fernandez-Baqueiro LE, Moreno EI. Out-ofplane behaviour of confined masonry walls. Eng Struct 2011;33:1734-41. doi:10.1016/j.engstruct.2011.02.012.

[40] Varela-Rivera J, Moreno-Herrera J, Lopez-Gutierrez I, Fernandez-Baqueiro L. Out of Plane Strength of Confined Masonry Walls. J Struct Eng 2012;138:1331-41. doi:10.1061/(ASCE)ST.1943-541X.0000578.

[41] da Porto F, Guidi G, Dalla Benetta M, Verlato N. Combined In-Plane/Out-of-Plane Experimental Behaviour of Reinforced and Strengthened Infill Masonry Walls. 12th Can Mason Symp 2013:1-11.

[42] Hak S, Morandi P, Magenes G. Out-of-Plane Experimental Response of Strong Masonry Infills. Second Eur. Conf. Earthq. Eng. Seismol., Istanbul: 2014, p. 1-12.

[43] Furtado A, Rodrigues H, Arêde A, Varum H. Experimental evaluation of out-of-plane capacity of masonry infill walls. Eng Struct 2016;111:48-63. doi:10.1016/j.engstruct.2015.12.013.

[44] Akhoundi F, Vasconcelos G, Lourenço PB, Silva LM. Out-of-plane response of masonry infilled RC frames: Effect of workmanship and opening. 16th Int. Brick Block Mason. Conf., 2016, p. 1147-54.

[45] Wang C. Experimental Investigation on the Out-Of-Plane behaviour of concrete masonry infilled frame. Dalhousie University Halifax, Nova Scotia, 2017.

[46] Sepasdar R. Experimental investigation on the out-of-plane behaviour of concrete masonry infilled RC frames. Dalhousie University Halifax, Nova Scotia, 2017.

[47] Ricci P, Di Domenico M, Verderame GM. Experimental assessment of the inplane/out-of-plane interaction in unreinforced masonry infill walls. Eng Struct 2018. 
doi:10.1016/j.engstruct.2018.07.033.

[48] De Risi MT, Di Domenico M, Ricci P, Verderame GM, Manfredi G. Experimental investigation on the influence of the aspect ratio on the in-plane/out-of-plane interaction for masonry infills in RC frames. Eng Struct 2019;189:523-40. doi:10.1016/j.engstruct.2019.03.111.

[49] Di Domenico M, Ricci P, Verderame GM. Experimental assessment of the out-of-plane strength of URM infill walls with different slenderness and boundary conditions. Bull Earthq Eng 2019. doi:10.1007/s10518-019-00604-5.

[50] Akhoundi F, Vasconcelos G, Lourenço P. Experimental Out-Of-Plane Behavior of Brick Masonry Infilled Frames. Int J Archit Herit 2020.

doi:10.1080/15583058.2018.1529207. 